WPS4066

\title{
A Dime a Day \\ The Possibilities and Limits of Private Schooling in Pakistan
}

\author{
Tahir Andrabi (Pomona College) ${ }^{1}$ \\ Jishnu Das (World Bank) \\ Asim Ijaz Khwaja (Harvard University)
}

\begin{abstract}
This paper looks at the private schooling sector in Pakistan, a country that is seriously behind schedule in achieving the Millennium Development Goals. Using new data, we document the phenomenal rise of the private sector in Pakistan and show that an increasing segment of children enrolled in private schools are from rural areas and from middle-class and poorer families. The key element in their rise is their low fees-- the average fee of a rural private school in Pakistan is less than a dime a day (Rs.6)! They hire predominantly local, female and moderately educated teachers who have limited alternative opportunities outside the village. Hiring these teachers at low cost allows the savings to be passed on to parents through very low fees. This mechanism - the need to hire teachers with a certain demographic profile so that salary costs are minimized-defines the possibility of private schools - where they arise, fees are low. It also defines their limits. Private schools are horizontally constrained in that they arise in villages where there is a pool of secondaryeducated women. They are also vertically constrained in that they are unlikely to cater to the secondary levels in rural areas, at least until there is an increase in the supply of potential teachers with the required skills and educational levels.
\end{abstract}

\section{World Bank Policy Research Working Paper 4066, November 2006}

The Policy Research Working Paper Series disseminates the findings of work in progress to encourage the exchange of ideas about development issues. An objective of the series is to get the findings out quickly, even if the presentations are less than fully polished. The papers carry the names of the authors and should be cited accordingly. The findings, interpretations, and conclusions expressed in this paper are entirely those of the authors. They do not necessarily represent the view of the World Bank, its Executive Directors, or the countries they represent. Policy Research Working Papers are available online at http://econ.worldbank.org.

\footnotetext{
${ }^{1}$ Corresponding author: Tahir Andrabi (tandrabi@pomona.edu). We thank Mehnaz Akber for early discussions and Safi Qureshey Foundation for initial financial support. We thank Tara Vishwanath, Michelle Riboud, Harold Alderman and Elizabeth M. King for useful comments. This research was funded by grants from the Poverty and Social Impact Analysis and Knowledge for Change Program Trust Funds and the South Asia region of the World Bank.
} 


\section{Introduction}

The 2000 Millennium Development Goals (MDGs) created a powerful global consensus to improve the development of poor countries by 2015. Central to this promise are the MDGs related to educational outcomes: (1) Ensure that all children complete primary education by 2015. (2) Eliminate gender disparities in primary and secondary education by 2005. By 2006, most countries have already fallen well behind the necessary targets to meet these goals. These worrying trends led to renewed calls for greater public investment in schools through school construction, teacher training programs and cash transfers for children. Notably absent in the proposals has been any role for private schools. ${ }^{2}$

One reason why private schools have never been seen or used as an instrument for mass education is that they typically serve the elite. In the US, 4 percent of low-income families send their children to private schools compared to 19 percent among the rich. Of parents with less than high school education, only 3 percent send their children to private schools compared to 19 percent for parents with graduate or professional degrees. ${ }^{3}$ Moreover, the share of private schooling is higher in tertiary and secondary education compared to primary education, by which time a large share of children from poor families have dropped out. These patterns are not unique to the US. The share of private schooling is higher in secondary compared to primary education in the majority of countries worldwide; in others the difference is fairly low and usually associated with the high state funding of private schools (Belgium, Spain, Netherlands and Chile are four such examples). ${ }^{4}$

In contrast, South Asian countries such as Pakistan, Bangladesh and India all show high shares of private enrollment at the primary level. Countries such as Zimbabwe in Sub-Saharan Africa as well as Lebanon and the gulf-states in the Middle East also stand out, with both high private school enrollment and a larger private sector share at the primary level.

We focus our attention on Pakistan, a country that is severely off-track in achieving the MDGs and where the role of private schools is strongly debated in academic, popular and policy writings. ${ }^{5}$ A substantial part of this debate is framed in terms of the "rising fees" and limited access to these schools in rural areas, concerns strongly voiced in the government's recent policy statement on private schools:

\footnotetext{
2 The United Nations (2005)

${ }^{3}$ NCES (1995), Table 1.5

${ }^{4}$ Based on the World Bank’s Edstats database, available at http://www1.worldbank.org/education/edstats/

${ }^{5}$ See Rahman (2005) and Abbas (2006)
} 
"It is argued that because of immense resource requirement, it is difficult for the government to achieve the objective of universalization of primary education. Accordingly, the opening of primary schools in the private sector is considered additionally to the effort of the government towards universalization. This is not a legitimate argument. The participation rates being already higher in urban settlements, it is in the rural areas that more schools are needed. The type of clientele going to these schools would any way participate in education. Thus, their role in universalization remains only marginal. Furthermore, because of the use of English as a medium of instruction, and high fee structure, these institutions are best suited to serve the requirement of elite population. Such a development is contradicted if effort is to be directed towards the development of an egalitarian society." 6

A specific picture of the private sector is painted whereby (a) private schools charge high fees; (b) private schools locate typically in urban areas and (c) private schools cater to an "elite population”. Neither this debate nor this characterization is unique to Pakistan. ${ }^{7}$

Using newly available data we present a starkly different picture of private schooling in Pakistan. There was a phenomenal rise in the share of the private sector in educational provision during the 1990s and an increasing segment of children enrolled in private schools are from rural areas and from middle-class and poorer families. We submit that private schools are better able to adapt to local conditions and use local labor markets in a cost-effective manner, allowing the savings to be passed on to parents through very low fees. The median fee of a rural private school in Pakistan is less than a dime a day (Rs.6 per day, or Rs.120 per month). If replicable in other countries, the results suggest that separating the financing of education (the government) from the provision of education (through the private sector) will have large gains, without necessarily sacrificing equity. ${ }^{8}$

Two considerations drive our focus on Pakistan. First, the extent of private schooling in Pakistan is striking. In 2000, 35 percent of children enrolled in school at the primary level were in private schools, and this number falls by a third for middle and high schools to 25 percent. Private schooling in Pakistan at the primary level is large, widespread and increasing over time. Second,

\footnotetext{
${ }^{6}$ See Ministry of Education (2006)

${ }^{7}$ See The Bangladesh Observer (2004).

${ }^{8}$ In the broader South-Asian context, Kingdon (1996 and 1998) first looked at private schools in the Indian context, where the private sector accounts for 15 percent of all enrollments; more recent contributions include Bajpai, Dholakia and Sachs (2005). The proliferation and nature of private schools in India appears to be similar to that in Pakistan. For in stance, Tooley (2001, pg.13) observes:

"Any visitor to the 'slums' of any of the big cities in India will be struck by the sheer number of private schools-there seems to be one on almost every street corner or down every alleyway. Some of these confusingly follow what they see as an English tradition and call themselves public schools but they are wholly private in every way and are certainly not elite institutions."
} 
Pakistan is the only low-income country, to our knowledge, that has a high quality census of all private schooling facilities in the country. These data allow us to understand the structure of private schools throughout the country; the large sample size permits useful comparisons even in regions where the extent of private schooling is smaller. Using this census of private schools in addition to representative household surveys from 1991 and 2001 and data collected by the authors, we document several patterns about the private schooling phenomenon in the country.

- The growth in private schooling is higher in rural compared to urban areas and is high even among the poorest segments of the population. What is equally remarkable is that these schools are overwhelmingly for-profit enterprises - they have sprung up around the country without much state regulation or subsidy. ${ }^{9}$

- Private schools charge (very) low fees. A typical private school in a rural village of Pakistan charges Rs.1000 (\$18) per year, which represents 4 percent of the GDP per capita for the country. In the US, private schools (elementary and secondary) charged $\$ 3524$ in 1991. At 14 percent of GDP per capita, the relative cost of private schooling is almost 3.5 times as high in the US compared to Pakistan. ${ }^{10}$

- The key to charging low fees is keeping costs down. Since teachers' salaries constitute the bulk of educational budgets around the world, lowering wages significantly reduces the overall cost of providing education. Private schools employ young, single, moderately educated and untrained local women. Since alternative employment opportunities for these women are limited, they are paid considerably lower wages than their male counterparts.

- These mechanisms define the possibility of private schools as well as their limits. Where private schools arise, the use of locally educated women and the structure of the labor market allow them to charge low fees. Where they exist, they are affordable. However, private schools do not exist everywhere; in particular they are constrained by the availability of teachers and potential demand side considerations reflecting the size of the village. Private schools are therefore not accessible to all. Since available teachers in rural areas are typically (just) secondary-educated, privates schools are also by necessity limited to the primary schooling market. It is unlikely that private schools will cater to the

\footnotetext{
${ }^{9}$ Private schools are secular schools, the majority of whom do not receive any funding from either the government or private agencies. A recent study by the authors (Andrabi and others 2005a) shows that religious schools play a much smaller role in Pakistan than believed. The share of religious schooling is less than one percent, lower than enrollment in religious institutions in the US. Most private schools in Pakistan do not receive any external funding, which makes them equivalent to the private unaided schools in India, for instance. This is in sharp contrast to (say) Indonesia, where private schools receive significant subsidies from the government (James, King and Suryadi 1996).

${ }^{10}$ National Council on Educational Statistics (1995) Table 1.5.
} 
secondary or tertiary sector, at least until a cohort of college-educated teachers is available locally.

Understanding the evolution of the private sector for education in Pakistan has wider implications. Governments in low-income countries around the world are struggling to meet the educational demands of an ever increasing young population. In Pakistan half the population is less than 17 years old and this proportion is increasing. With less than 60 percent of children enrolled in school, there are already signs of stress. Mean student-teacher ratios in government schools exceed 35 and have been rising. School construction has slowed down and less than half of all classrooms have desks for their children. Private schools can play a role in breaking these institutional constraints, and the Pakistani experience demonstrates that they can do so without catering only to the elite.

The remainder of this paper develops the ideas advanced here. In Section II we describe our data sources. Section III examines the growth of private schooling in Pakistan. Section IV takes a closer look at how private schools operate. We document fees and costs for private schools and examine teacher profiles and wage differentials between public and private schools. Section V concludes with a discussion of educational policy, caveats and future research in this area.

\section{Section II. The Country Context and the Data}

Pakistan has 132 million people and is organized in a federal structure with four main provinces-Punjab, Sindh, North Western Frontier Province (NWFP) and Balochistan. These four provinces, along with Islamabad, the federal capital, comprise 97 percent of the country's population. Punjab is the largest province with 56 percent of the population and Sindh, NWFP and Balochistan account for 23 percent, 13 percent and 5 percent respectively. There are other regions and territories where special constitutional and legal qualifications apply. The Federally Administered Tribal Areas (FATA) with 3 percent of the population has representation in the national assembly but national laws apply only partially. The Northern Areas and Azad Jammu and Kashmir (AJK) enjoy special status and their population is not counted in population census numbers. Provinces manage the provision of education, although there are recent changes at the local government level that aim to devolve provision to the numerous districts within every province.

Educational performance is poor both in absolute terms and relative to the average income of the country. Pakistan has an adult literacy rate of 44 percent compared to 54 percent for the South 
Asia average, and in 2001-02, net-enrollment was 51 percent compared to 83 percent for India, 90 percent for Sri-Lanka and 70 percent for Nepal. For the country's level of income, the forecasted net enrollment rate (based on a regression of primary net enrollment on log per-capita income and the square of log per-capital income for 138 countries) is 77 percent: Pakistan's net enrollment is thus far below what one would expect for its level of income.

The problem of low overall educational performance is further compounded by large gender, income and geographical disparities. There is a 20 percentage point difference in gross enrollment rates at the primary level between boys and girls and in some provinces, notably NWFP and Balochistan, this difference increases to 40 percentage points (PIHS 2001-02). Wealth also matters: at the primary level gross enrollment rates for the top expenditure-decile is twice as high as for the lowest decile. Finally, the rural-urban divide is large with a net-enrollment ratio of 45 percent in rural areas compared to 66 percent for the urban areas. Net-enrollment ratios for rural females, at 36 percent, are therefore the lowest for any sub-group of the population.

Private education in Pakistan has a long history dating back to before independence in 1947. Limited data suggest that private schools catered to a niche market restricted to big cities from 1947-1972, dominated by missionary-run schools or local schools imitating the missionary model, and were mainly used by the elite. In 1972 private schools were nationalized amidst a government program of nationalization of all industry. The policy was reversed in 1979 through a process of denationalization. Private schools were allowed to open and the schools taken over by the government were gradually returned to the original owners. However, government policy towards private schools was and still is one of laissez faire-there are no subsidies in the form of grants to parents or schools (as in Bangladesh, the Philippines or India) so that private schools arise and survive purely as a market based phenomenon.

\section{The Data}

We employ four primary government data sources and data from a comprehensive education survey on Learning and Educational Achievement in Punjab Schools (henceforth LEAPS), collected by the authors. Our government sources are the 1998 Population Census, the Punjab Educational Management Information Systems, the Census of Private Educational Institutions in Pakistan (PEIP), and the Pakistan Integrated Household Surveys (PIHS). In brief, the Population Census is the decennial census conducted by the Population Census Organization provides information on village level attributes for every village in Pakistan. The census of private educational institutions was conducted by the Federal Bureau of Statistics in 2000 and provides 
information on all private schools in the country at that time. The Educational Management Information Systems (EMIS) is collected by the provincial Education departments and provides information on public schools; due to data limitations we use the EMIS for Punjab province only (more on this below). Finally, the Pakistan Integrated Household Survey (PIHS) conducted also by the Federal Bureau of Statistics is a nationally representative household survey carried out in 1991, 1998 and 2001. We use the 1991 and 2001 rounds to examine the growth of private schooling across provinces, the rural/urban divide and across income groups, and the 1998 round to look at enrollment differences between the rich and the poor in villages with and without private schools. ${ }^{11}$

These data were linked through an extensive matching process so that we could examine schoollevel attributes in conjunction with village-level data such as population and village infrastructure. There was a 100 percent match between the population census, the census of private schools and the PIHS since these were collected by the same agency. The EMIS data was collected by the provincial government and had a different coding scheme. To match these data at the village-level we used text-matching algorithms followed by a manual match. This process allowed us to match 85 percent of the schools in the EMIS database with the census; for these villages, we then have complete data on both village-characteristics and the existence of public and private schools. ${ }^{12}$

In addition to these government data sources, data on teachers' profiles and wages were collected in 2004 as part of an ongoing project—Learning and Educational Achievement in Punjab Schools (LEAPS). A unique characteristic of this data is the sampling frame, which was constructed in two stages. In the first stage we stratified the province of Punjab in three regions-North, Central and South—and chose one district from each region. ${ }^{13}$ In the second stage, villages were chosen randomly in each of these districts from a list frame of villages with at least one private school. The sampling-frame allows us to examine variation in teacher's wages across public and private schools in the same village, thus abstracting from differences due to geography, labor market segmentation or other village specific features. Across the three districts, our sample consists of 4,880 teachers interviewed in 800 public and private schools in 112 villages.

\footnotetext{
${ }^{11}$ In order to do so, we need the names of villages where the surveys were conducted. We have access to the list of villages for 1998, but not 2001.

${ }^{12}$ The problem is somewhat complicated since there is no standardization of transliteration of village names into English. The same village names can be spelled quite differently in the two data sets.

${ }^{13}$ The choice of one district each from North, Central and South Punjab follows an accepted stratification in the Province, where the Southern districts are typically thought to be the least developed followed by the center.
} 


\section{Section III. The Rise of Private Schooling}

Based on a school mapping exercise conducted in 1983, Jimenez and Tan $(1985,1987)$ noted a large increase in the number of private schools after denationalization, leading to substantial cost savings for the government in the provision of education. The authors noted (cautioning that the available data did not allow for an unambiguous statement) that despite the growth in private schools, educational institutions still did not service large proportions of the country's population; particularly troublesome was the exclusion of girls in rural areas. Based on tuition and other fees in private schools, they argued that private schools were catering only to the rich and concluded that the private education sector would reach "full-capacity" at an enrollment of 2.1 million children.

Fifteen years after Jimenez and Tan's (1987) assessment, there are 6.3 million children enrolled in more than 36,000 private institutions in Pakistan. From the 3,300 private schools in the four big provinces (Punjab, Sindh, NWFP and Balochistan) in 1983, there were 32,000 such schools in the same four provinces in 2000-an almost ten-fold increase in less than two decades. Enrollment in these private schools is mostly at the primary level, accounting for 75 percent of the total enrollment in private schools. As a share of total enrollment, 18 percent of children in the 5-10 age-groups, 9 percent of the 11-13 age-group and 4 percent of the 14-16 age-group was attending private schools. Since a large fraction of children of all age groups are not enrolled in any type of school, private school enrollments account for 35 percent of public enrollment across primary, middle and high schools.

The boom in private schools happened during the 1990s (Figure 1). The median year of formation for a private school that was functional in 2000 is 1996; 22 percent of schools in 2000 were formed in 1998 and 50 percent were less than 4 years old (formed on or after 1996). ${ }^{14}$ While the majority of existing schools formed before 1990 were urban, since then there has been a qualitative shift with a steady increase in the rural/urban ratio till 1996, followed by a leveling

\footnotetext{
${ }^{14}$ Interpreting these figures as the growth-rate of private schools in recent years is problematic since data on the age of schools currently existing does not yield information about school survival rate. If, over a 3year span, 1000 schools were set up each year but 500 shut down a year later, a survey after three years would report 125 schools aged 3 years, 250 schools aged 2 years, 500 schools aged 1 year and 1000 schools established in the current year. The difference in these numbers is due to the school survival rate rather than the growth of schools. To some extent we can separate the joint effect of school formation and school survival rates through a simple exercise based on data from 1983: In 1983, there were 3300 private schools in the four provinces. In contrast, the current census indicates that by 2000 there were 1,764 private schools formed in 1983 or before in these provinces, suggesting that a bit over half the schools survived over the 17 -year period i.e. an implied annual survival rate of 96.4\%. Discounting the numbers that Figure 2 is based on by the survival rate still yields substantial growth in private schools during the 90s.
} 
off. Since 1996 onwards, an equal number of private schools were set up in rural and urban areas every year and in 1999, there were 8,000 new private schools setup in Pakistan, almost half of which were in rural areas.

The dramatic increase in the setting up of private schools translated directly into a greater enrollment share for the private sector. All four main provinces registered consistent increases in the share of private schooling in total enrollment between 1991 and 2001, although their specific experiences varied: the largest increases were in Punjab and NWFP (from 15 to 30 percent and 4 to 17 percent respectively) while the growth in Sindh (16 to 21 percent) and Balochistan (4 to 6 percent) was more muted. ${ }^{15}$

The enrollment share of the private sector increased both in urban and rural areas, and for both the rich and the poor. Between 1991 and 2001, for the poorest decile of per-capita expenditure in rural areas, the share of private schools increased from 0 to 6 percent; for the richest rural deciles the share jumped from 12 to 38 percent. Urban areas reported equally high growths, although from a higher initial level. For the poorest deciles, the equivalent increase was from 9 to 18 percent and for the richest from 52 to 85 percent. By the end of the nineties, nearly all rich Pakistani children in urban areas, almost a third of the richer rural children and close to 10 percent of children in the poorest deciles nationally were studying in private schools.

Figure 2 examines this change using growth enrollment curves. We computed the growth in private and public enrollment for every decile based on household consumption expenditure data from the PIHS in 1991 and 2001. The horizontal axis in the figure shows the relevant decile in 1991 and 2001 where 1 is the poorest and 10 the richest. The vertical axis shows the growth in enrollment, defined as ((Enrollment ${ }_{2001}$ - Enrollment $\left.{ }_{1991}\right) /$ Enrollment $\left._{1991}\right)$ for the relevant decile. Nationally, decadal enrollment growth rates in the private sector were higher among the poor (close to 300 percent) and lower among the rich (150 percent) and middle-income groups in rural areas registered the highest growth rates (close to 400 percent). There was a decline in public school enrollment growth rates, both across urban and rural areas and across the rich and the poor, although these declines were more marked for the rich.

The 1990s saw the single biggest shift in the structure of educational delivery in Pakistan and contrary to popular belief, religious schooling played no role in this structural shift. Secular

\footnotetext{
${ }^{15}$ All enrollment comparisons between 1991 and 2001 are based on enrollment and household consumption expenditure data from the PIHS in 1991 and 2001.
} 
private schools gained significantly in the share of overall primary enrollment and their gains were across all provinces, across rural and urban areas and for both the rich and the poor. Nevertheless, towards the end of the 1990s, there were still large areas of the country, such as rural Balochistan and Sindh, where private schools had not made any inroads. This uneven spread of private schools allows us to better understand the causes of their spectacular growth as well as its limitations.

\section{Section IV. The Private Schooling Story}

Seven figures and tables illustrate different facets of the private schooling story; together they present a landscape where (a) educational outcomes are closely linked to the presence of a private school and (b) the presence of a private school relies critically on the availability of educated women in the village. A key message emerges: where private schools arise, they are affordable and used by the poor, but private schools do not arise everywhere. Indeed, the same mechanism that ensures their affordability also constrains where they locate.

\section{$\underline{\text { Schooling Outcomes in Villages with and without Private Schools }}$}

The first table shows differences between villages with and without private schools in schooling outcomes and the relative use of private schools by the rich and the poor using matched data from the census of private schooling (PEIP, 2000) and the Pakistan integrated household survey (PIHS, 1998). We present results for the country as a whole (Column 1, Table 1) and the four main provinces separately (Columns 2-5, Table 1). Several features of this comparison are noteworthy.

As expected, private school enrollment is higher in villages with private schools, and in both villages with and without private schools the rich use private schools more than the poor (note that even in villages without private schools, some parents send their children to private schools outside the village). In all four provinces, the share of private enrollment is twice as high in villages with private schools compared to those without: in Punjab, for instance, in villages with private schools, 23 percent of enrollment is in private schools compared to 11 percent in villages without. For the four main provinces, the share of private schooling among the rich is double that of the poor in villages with private schools, and almost four times as high in villages without. The pattern repeats across all four provinces, with the exception of Balochistan, where the size of the sample is too small for meaningful comparisons.

However, the use of private schools by the poor has as much to do with their availability as their costs conditional on location. Where there are private schools in the village, a sizeable fraction of 
the poor use them: in Punjab, in villages with private schools, the share of private schooling in total enrollment for the poorest one-third is 15 percent and among the richest one-third 29 percent. Remarkably, for the country as a whole, the fraction of private enrollment for the poor in villages where there are private schools (13 percent) is greater than the share of private enrollment (11 percent) for the rich in villages where there are none.

Finally, the existence of private schools is strongly associated with greater female education. In both Punjab and NWFP, there is a large and significant difference of close to 20 percentage points in overall female enrollment in villages with private schools compared to those without. Comparisons of the gender-ratio in private and public schools show that a dramatic impact of the penetration of private schools is that there is a smaller gender gap in private school enrollment across the country-the share of female enrollment in private schools is consistently 3-5 percentage points higher than in government schools in educational data from all available sources. ${ }^{16}$

The LEAPS data provide further evidence on the association between enrollment and the presence of private schools by looking "inside” villages and contrasting enrollment patterns in settlements with and without private schools. ${ }^{17}$ Figure 3 shows male and female enrollment in settlements with and without private schools for the 112 villages in the survey. There is a 21 percentage point increase in male enrollment and a 29 percentage point increase for female enrollment (which is lower in every category) in settlements with private schools compared to those without and a 29 percentage point increase for female enrollment.

Table 2 looks at the association of school-presence and enrollment in a multivariate regression context. The first two columns presents differences between households located in settlements with and without private schools; the first column is a cross-section regression while the second introduces village-level fixed effects. As expected, enrollment increases sharply with age but the increases taper off as the child becomes older (the negative coefficient on the square term in age). Also as expected, the income and education of the household significantly increase enrollment levels for children.

\footnotetext{
${ }^{16}$ The difference using the PEIP census and EMIS numbers is 37 percent vs. 42 percent in 1999-00 and 40 percent vs. 44 percent in PIHS 2000 data.

${ }^{17}$ Using geographical markers, we divided every village into "settlements”; for the sample of 112 villages, there are 215 settlements.
} 
Of particular interest are the effects on enrollment of being female, of having a private school in the settlement and the differential effect of being a female in a settlement with a private school, which is captured by the interaction term. The presence of a private school in the settlement significantly increases enrollments for boys by 16.4 percentage points, but has a much larger effect on girls given by the additional interaction term of 8.1 percentage points. Put another way, in settlements without private schools, females are 16 percentage points less likely to be enrolled compared to boys. When there are private schools in the settlement, the enrollment of both genders increases, but female enrollment increases more so that the overall gender gap decreases to 8 percentage points.

Following Jacoby and Mansuri (2006), the next column (Column 3, Table 2) repeats the same regression with household fixed-effects. That is, we look at the differential effect of schoolpresence across girls and boys in the same household-doing so allows us to identify the differential effect of school-presence across genders while controlling for unobserved householdlevel omitted variables (for instance, households that care less about schooling may be located in settlements without schools). The gender penalty of school-presence is strong and significant: compared to a boy in the same household, a girl in a settlement without a private school is 18 percentage points less likely to be enrolled but this gap decreases to 9 percentage points in settlement with such schooling options. Private schools increase enrollments, more so for girls than boys and where they exist they are also used by the poor. The key to the use of private schools by the poor lies in their affordability. ${ }^{18}$

\section{$\underline{\text { Private School Fees }}$}

Earlier studies in smaller samples had shown that private schools charged very low fees. Alderman and others (2001) for instance, document that private school fees are affordable even for the poor in urban cities of Quetta and Lahore, charging an average of Rs.85/month in their

\footnotetext{
${ }^{18}$ These results contrast with the discussion in Lloyd, Meta and Grant (2006), who argue that private schools do not increase girls' enrollment, but locate where girls' enrollment was high to begin with. There are several problems with their interpretation. The evidence that private schools do not lead to higher girls' enrollment is drawn from 12 villages, of which only 5 do not have a private school in the second wave of their survey. They find no contemporaneous difference in female enrollments between the villages with and without private schools, which is not consistent with the nationally representative data in Table 1 . In their randomized treatment-control study, Alderman and others (2001) shows that the setting up of a private school leads to a 20 percentage point increase in female enrollment, which is very close to the numbers in Table 1. The argument that private schools locate in villages with higher girls' enrollment does not hold in larger samples either. Table 7 below will look at private school locations in villages with girls' primary schools and with girls' primary and secondary schools based on data from 26000 villages in Punjab province. We will argue that only the second type of school increases the likelihood of private school existence in the village. This has more to do with the availability of teachers than students, particularly since 90 percent of private schools in rural areas cater only to the primary sections.
} 
study. We bring country-wide data to show that fees are low for all the provinces in Pakistan, as well as for rural and urban regions within each province.

Table 3 shows median and mean fees for private schools in the four main provinces using data from the census of private schools. ${ }^{19}$ Median school fees in Pakistan are low: the highest median school fee in urban and rural areas is Rs.1757 and Rs.1265 annually, both for the province of Balochistan. Punjab, with more than 50 percent of the school going age population reports the lowest median annual fees in urban and rural regions (Rs.828 and Rs.600 respectively). In rural areas, the median annual fee translates to roughly 80 cents a month, or a nickel a day. Based on expenditure data from the PIHS, the mean tuition fee in Punjab represents 1.7 percent of average household expenditure in rural and 2.1 percent in urban areas. A family with 4 children in an urban area will spend 8.4 percent of their household budget on school tuition fees if all their children are enrolled in an average private school. ${ }^{20}$ The consistently higher mean compared to the median shows that the distribution is skewed to the left, with a high concentration of schools around lower school fees. The maximum inter-quartile range, which shows the range of fees between the schools at the $75^{\text {th }}$ and $25^{\text {th }}$ percentiles of the fee distribution, is Rs.1200 (urban Balochistan): in rural regions, 50 percent of all schools are concentrated in a tight band ranging from Rs.900 to Rs.1500.

A striking aspect of Table 3 is that provinces with more schools report lower median fees. If private schools respond to higher local demand for quality education, we expect the opposite relationship to hold-private schools arise where people are willing to pay more for education; therefore, the extent of private schooling should be positively correlated with fees. The data is more consistent with the hypothesis that the existence of private schools is constrained not by the demand for such schooling, but by the availability of teachers. Private schools arise where teachers are available. Since the presence of private schools is a response to an increase in supply, fees are lower in areas where their penetration is higher.

\section{Teachers (and Their Wages) in Private Schools}

Table 4 is a first look at the importance of teachers in the private schooling story. The first row in the table compares salaries in the private and public sector using data on 4,890 teachers in the 800 public and private schools of the LEAPS study. The difference in pay between a teacher in a

\footnotetext{
${ }^{19}$ We eliminate a small number of NGO schools that are subsidized by donors and may charge lower fees.

${ }^{20}$ Note that total expenditure in schooling includes more than just tuition fees and these numbers therefore represent an underestimate of the total costs of schooling.
} 
private and a government school is staggering. An average female teacher in a government school earns Rs.5897 per month, which is not very different from the earnings for an average male (Rs.6408). Among private schools though, male teachers earn Rs.1789 per month (almost onethird!) while females earn only half as much at Rs.1069.

Two factors drive these salary differences between the public and private sectors: (a) differences in teacher characteristics and; (b) differences in the returns to characteristics. Teacher characteristics in the public and private sector are clearly very different (Table 4). Private schools hire female teachers (76 percent compared to 43 percent in government schools) who are substantially younger (25 years versus 38 years for public school teachers), less likely to be married (77 percent are single versus 15 percent), twice as likely to come from the village where they are teaching (52 percent versus 25 percent), less educated (4 percent have a masters degree compared to 19 percent) and far less likely to have received any educational training (6 percent versus 71 percent).

The returns to characteristics are also different. Table 5 presents multivariate regressions of (log) teacher wages on observed characteristics including age, education, teacher-training, gender and place of residence (whether local or not). The first two columns show how different characteristics are compensated by public and private schools respectively, while the third column examines differences between public and private school compensation through interaction terms. Since the LEAPS data is based on a sampling scheme that guarantees multiple schools in every village, we can also look at the difference among teachers in the same village; the fourth column looks at differences within villages through a fixed-effect regression at the level of the village.

Salaries for public school teachers respond strongly to education and training but not to the gender of the teacher. Private sector salaries also respond to education, but not to teacher-training and females are paid considerably less. Surprisingly, there are few differences in the estimated coefficients in specifications with and without geographical controls (Column 3 vs. Column 4, Table 5). Using these regressions for the public and private sectors, Figures 4 and 5 highlight the separate roles of characteristics and returns to characteristics. 
Figure 4 illustrates the thought experiment of moving a teacher from the public sector and paying her/him the salary that would be associated with her characteristics in the private sector. That is, we use the estimated coefficients from Column 1 in Table 5 to predict what private sector salaries would be for teachers with characteristics observed in the public sector. The figure plots the average pay of a teacher in the public sector (the first bar), a teacher in the private sector (the second bar) and a teacher in the private sector if he/she had the same characteristics as teachers in the public sector. The difference between the first and the third bar is the difference in salaries arising from differential returns in the two sectors; the difference between the second and the third bar is the difference due to characteristics.

There is a dramatic decrease in the public sector teacher's salary if she were to move to the private sector. The average salary for the public sector teacher falls from Rs.5620 to Rs.1765. This is because the private sector does not value teacher training (which the public sector does), it does not compensate experience to the same level as the public sector, and it pays female teachers a lot less. The remaining difference with the average salary in the private sector, Rs.1084 vs. Rs. 1765, is because of differences in teacher characteristics. Public sector teachers are more educated and this is reflected in their higher wages. ${ }^{21}$

Figure 5 looks at differences in returns for the private and public sector for three particular characteristics - teacher gender, origin and training. The horizontal axis shows the salary penalty (negative) or premium (positive) associated with these characteristics in the two sectors. After controlling for observed characteristics, female teachers earn slightly more (not significant) in the government sector but 33 percent less in the private sector. In both sectors local teachers are paid less, but the penalty in the private sector (23 percent) is much larger than in the government sector (6 percent). Finally, the public sector cares a lot about teacher training while the private sector does not. Teachers with a Primary Teacher Certificate (PTC) earn 75 percent more in the public sector and only 3 percent more (not significant) in the private sector.

\footnotetext{
${ }^{21}$ This is the familiar Oaxaca-Blinder decomposition in the labor economics literature. As is well understood, choosing the correct reference group affects the interpretation of the decomposition. If we perform the reverse experiment of moving a private sector teacher to the public sector, her salary would increase from Rs.1084 to Rs.1895, primarily because the public sector values teacher-training and most private sector teachers are not trained. An alternative is to use the pooled data as the reference group, where as expected, the estimates are in between the two experiments discussed here.
} 
The critical insight is that by basing hiring decisions and linking pay closely to local labor market conditions private schools have kept their costs low. Compensation in the government and private sector works in very different ways: teachers in the government sector are paid on the basis of a pay-scale that rewards experience and training, but does not respond to local labor market conditions. In contrast, the private sector values teacher education, but also compensates teachers according to their other available opportunities in the labor market. With fewer occupational opportunities women are restricted to the village in their job-search so they are paid less. ${ }^{22}$ Bringing a teacher from outside the village means that the school has to pay more for travel, so non-local teachers are paid more. It is also interesting to speculate on why the market does not value teacher-training. In related work we show that there is no relationship between teacher training and either teacher competency or their children's academic performance. A recent report confirms that training programs are in crisis and add little to the teachers' efficacy (Ali Institute 2005). A striking, but perhaps valid, hypothesis is that the market does not value training because training does not add any value. There are thus two steps that account for the success of the private educational sector in Pakistan:

- Hire teachers whose characteristics do not command high salaries in the labor market. Private school teachers are overwhelmingly women and are less educated than in the public sector; if private school teachers had the same characteristics as those in the public sector, the market would reward them with a 63 percent increase in salaries (instead of the 518 percent that teachers in public schools currently enjoy).

- React optimally to local labor market conditions. Women and local teachers are paid less in the private sector, but not in the public sector.

\section{Where have private schools located?}

The very factors that explain the success of private schools also embed their potential limitations. Private schools need a large number of children in the catchment population and they need a pool of potential teachers with a certain demographic profile (local women with secondary education). A matched database that combines village characteristics and private school existence allows us to examine village-level variables that increase the likelihood of a private school.

\footnotetext{
${ }^{22}$ The data from the LEAPS survey is corroborated by data from the wider labor market beyond that of teachers. Wage differences between men and women in Pakistan are staggering. Analysis based on household surveys show that men receive four times as much as women when they have primary education and two times as much when they have secondary education (World Bank 2005). That educated women cost less is in large part due to different constraints on labor mobility of men and women. While men can (and often do) travel outside their residential areas to pursue employment opportunities, cultural constraints and issues of safety restrict work options for women to the settlement that they live in (World Bank 2005).
} 
Private schools locate in villages with larger populations and better infrastructure across the four provinces (Table 6). Villages where there are private schools are roughly twice as large in terms of population (4465) than those without (1502). Private schools are also in villages where infrastructure is better. Across all four main provinces, 73 percent of houses report an electricity connection in villages where there are private schools compared to 44 percent in villages where they are not. The same pattern repeats for piped water supply. The average fraction of houses with permanent construction (a plausible measure of village wealth is the fraction of houses with pakka (permanent) construction rather than mud or thatch) in a village with private school is 60 percent compared to 36 percent in villages without private schools.

However, village size and wealth are not the unique determinants of private school location. Private schools also tend to locate in villages where there are women with secondary education. In the case of Punjab, increasing the percentage of educated (older) females in the village by one standard deviation increases the number of private schools in a village by 0.51 standard deviations. More compellingly, the likelihood of having a private school in a village more than doubles when a village has a girls public secondary school (compared to a village that does not have a girls' school), increasing from 11.6 percent to 30.79 percent, but is no different when the village has only a girls’ primary school (Table 7). In Andrabi, Das and Khwaja (2006) we tested this prediction using an instrumental variables strategy and confirmed that the prior construction of a girls' public secondary school increases the likelihood of a private school by almost three times and furthermore, such construction is associated with a decline in teachers' wages in private schools. Private schools have overwhelmingly located where the government set up girls' secondary schools in the last twenty years.

\section{Section V. Discussion and Caveats}

Private schools have effectively used less educated, low paid young women to serve as primary grade teachers. This formula for success may not be replicable at the secondary and the highersecondary level, since the required skill and educational levels are just not locally available in most of rural Pakistan. To expand to this level, private schools will be forced to hire teachers from outside the village, dramatically increasing salary costs. Thus the affordability of private schools stemming from the low labor costs will be compromised. The spread of private schools, therefore, is constrained both geographically - they will first come up in villages where there is a ready stock of educated women - and vertically by the availability of trained teachers at the local level. 
The debate between private and public schooling focuses on substitution between private and public enrollment, where increasing enrollments in one is seen as the decline in the share of the other. While the two are indeed alternate sources of education and hence substitutes at any given time, the success of private schools in Pakistan is based on their overwhelming reliance on locally based teachers who are female. But where do these locally based females with secondary education come from in the first place? Pakistan's case adds a temporal dimension to the debate on public versus private schooling, introducing complementarities between the two sectors. Girls educated in today's public schools will become teachers in tomorrow's private schools. Viewed in this light, a first priority should be the development of a cohort of educated women in every village who can then serve as catalysts in the process of educational reform. Dynamic complementarities between the public and private sector suggest that a first large investment, a "Big Push" in creating cohorts of educated women could then lead to self-sustaining growth in educational provision through the use of private schools. Alternatively, to alleviate the constraints of low cost teachers, it has to become easier for women from the outside to break into the village labor market. Educational policy in Pakistan needs to take into account the segmented nature of labor markets and the dynamic complementarities that exists between public and private schools.

Our focus on the supply constraints to education and the central role of women as teachers is not new. In the US there has been an extensive debate about the relationship between changing educational quality and the exit of women from the teaching profession. Two reasons-the opening up of alternative employment options and increased unionization—have been advanced as potential explanations for this compositional change in the teaching workforce. As the labor force participation of women in Pakistan increases, it is likely that similar patterns will emerge. Pakistan at this stage presents a fascinating glimpse of an environment that many higher-income countries witnessed 50 years ago.

There are important aspects of private schools that we have not touched on here. For instance, more than 92 percent of private schools in both rural and urban areas of Pakistan are coeducational. They are co-educational not only in the less conservative provinces such as Punjab (94 percent), but also in provinces with lower human-development indicators and typically more conservative attitudes, such as NWFP (88 percent) and Sindh (90 percent). A common wisdom in Pakistan is that girls will not go to school unless schools are single-sex. As Gazdar (2001) points out, this wisdom is not borne out by attitudinal surveys of parents towards primary schooling or systematic evidence from any part of the country. In fact, in certain cases, a large number of girls have started attending boys' primary schools when allowed to do so-distance seems to be a 
larger factor for non-enrollment in primary schools, rather than the presence (or not) of a segregated school (Holmes 2003, Lloyd, Mete, and Sathar 2005a, Alderman, Orazem and Paterno 2001). The advantages and experience with co-education and whether female teachers help attract girls to school is a critical issue for the development of private schools and for education in the country.

There are also certain questions left unanswered in our paper. To the extent that private schools save on costs by hiring local, female and moderately qualified teachers, are they compromising on quality? Figure 6 is a preliminary response to this concern. Here we plot teacher absenteeism for government and private schools separately for male and female teachers. ${ }^{23}$ Private school teachers are considerably less absent than government school teachers in a given month. Government school female teachers are absent more than twice as many days (4 vs. 1.8) in a month than their private school counterparts. So, if what really matters for primary schooling is that the teacher puts in effort, this may more than compensate for lower qualifications - a teacher with a $\mathrm{PhD}$ teaching in a primary school will have no impact if she never shows up for work. The extent to which qualification matters in teaching rather than effort remains an important research topic.

A second basic question is why people send their children to private schools. Is it because there is a perceived or actual quality difference between public and private schools? Can poor illiterate parents judge the difference between a good and a bad school? How do parents make decisions when offered more schooling choices? Answering these questions is essential because any educational policy that expands the educational space and does not take into account this dynamic of school choice is subject to essentially a version of the "Lucas" critique where the parental reaction to any policy could lead to policy ineffectiveness.

The third question left unanswered is the equity implications of private schooling. There is a growing concern in Pakistan that private education leads to the emergence of two classes-the English-medium trained elite and the vernacular Urdu-medium taught masses. This point has been raised numerous times in the popular press, by academics and by populist politicians. ${ }^{24} \mathrm{We}$ don't answer this question fully, but LEAPS and the PIHS data can shed some light on this. The rise of private schooling in the rural areas is likely to bring rural and urban areas closer in terms of quality education, and at the same time increase disparities within rural areas - that is, children

\footnotetext{
${ }^{23}$ See Banerjee and Duflo (2005) on importance of absent teachers.

${ }^{24}$ See Najam (1998), and The News, March 24, 2004 report on Imran Khan’s views on education. http://www.jang.com.pk/thenews/mar2004-daily/23-03-2004/metro/k11.htm
} 
in villages with private schools will enjoy educational opportunities that bring them closer to their urban counterparts; at the same time, children in villages without private schools will likely be left further behind.

Finally, we recognize that correlations are not evidence of causation. Our ongoing research in this area examines quality issues in private education and the interaction of private and public schooling, and focuses more centrally on establishing causality of the linkages mentioned here. 


\section{Bibliography}

Abbas, Andleeb, 2006, “A boxful of promises”, Magazine, The Daily Dawn, May 28, 2006. available at http://www.dawn.com/weekly/dmag/archive/060528/dmag1.htm

Alderman, Harold, Peter F. Orazem, and Elizabeth M. Paterno, 2001, "School Quality, School Cost, and the Public/Private School Choices of Low-Income Households in Pakistan." Journal of Human Resources 36(2): 304-326.

Alderman, Harold, JR Behrman, DR Ross, R Sabot, 1996, "Decomposing the Gender Gap in Cognitive Skills in a Poor Rural Economy”, The Journal of Human Resources, 31(1): 229-254.

Andrabi, Tahir, Jishnu Das and Asim Khwaja. 2006. "Students Today, Teachers Tomorrow: The Rise of Private Schools in Pakistan.” Processed. Harvard University, Cambridge, Mass.

Andrabi, Tahir, Jishnu Das, Asim Khwaja and Tristan Zajonc, 2005a, "Religious Education in Pakistan: A Look at the Data”, John F. Kennedy School of Government, Faculty Research Working Paper Series, Working Paper Number:RWP05-024, forthcoming, Comparative Education Review, Special Issue "Education in Islam: Myths and Truths”, August 2006

Andrabi, Tahir, Jishnu Das, Asim Khwaja and Tristan Zajonc, 2005b, LEAPS Report Chapter 1: Enrollment and Achievement, processed, The World Bank, Washington DC

Bajpai, Nirupam, Ravindra H. Dholakia and Jeffrey D. Sachs, 2005, "Scaling Up Primary Education Services in Rural India”, The Earth Instiute, Columbia University, CGSD Working Paper No. 28, November. Available at http://www.earthinstitute.columbia.edu/cgsd/bajpai_working_papers.html

The Bangladesh Observer, 2004, "Editorial: The Commercialization of Education”, Wednesday, July 7. available at http://www.bangladeshobserveronline.com/new/2004/07/07/editorial.htm

Banerjee, Abhijit and E. Duflo, 2005, “Addressing Absence”, Journal of Economic Perspectives, Vo. 20 (1), pp. 117-132

Gazdar, Haris, 2001, Policy Failure, Political Constraints and Political Resources: Basic Education in Pakistan, Asia Research Centre, London School of Economics, ARC Working Papers, WP5

Holmes, Jessica, 2003, "Measuring the determinants of school completion in Pakistan: analysis of censoring and selection bias”, Economics of Education Review, Volume 22, Issue 3, Pages 249-264

Jacoby, Hanan and Ghazala Mansuri. 2006. "Crossing Boundaries: Social Distance and the Gender Gap in Schooling in Rural Pakistan." Processed. The World Bank.

Jimenez, Emmanuel. and J. P. Tan, 1985, "Educational Development in Pakistan: The Role of User Charges and Private Education," Discussion paper and education training Series, Report no. EDT16, The World Bank, Washington D.C.

James, Estelle, Elizabeth M. King and Ace Suryadi, 1996, "Finance, Management and Costs of Public and Private Schools in Indonesia.” Economics of Education Review, 55(4): 387-398

Jimenez, Emmanuel and Jee-Peng Tan, 1987, "Decentralized and Private Education: the Case of Pakistan." Comparative Education 23: 173-90.

Kingdon, Geeta, 1996, "The Quality and Efficiency of Public and Private Schools: A Case Study of Urban India”, Oxford Bulletin of Economics and Statistics, 58, No.1: 55-80, February.

Kingdon, Geeta, 1998, “Does the Labour Market Explain Lower Female Schooling in India?” Journal of Development Studies, 35, No. 1: 39-65, October. 
Lloyd, Cynthia B., Cem Mete, and Monica J. Grant, 2005b, "The implications of changing educational and family circumstances for children's grade progression in rural Pakistan: 1997-2004," Policy Research Division Working Paper no. 209. New York: Population Council.

Lloyd, Cynthia B., Cem Mete, and Zeba A. Sathar, 2005a, "The effect of gender differences in primary school access, type, and quality on the decision to enroll in rural Pakistan,” Economic Development and Cultural Change 53(3): 685-710.

Lloyd, Cynthia B., Cem Mete, and Monica J. Grant, 2006. The Current Challenges to Achieving Universal Primary Enrollment for Girls in Pakistan.” Center for Global Development, Washington, D.C. Processed.

Ministry of Education, 2006, Government of Pakistan, “National Education Policy, 1998-2010”, Islamabad. Available at http://www.moe.gov.pk/

Najam, Adil, 1998, Educational Apartheid, Chowk.com, February 7, available at http://www.chowk.com/show article.cgi?aid=00000151\&channel=university\%20ave

National Council on Educational Statistics, 1995, "Private Schools in the United States: A Statistical Profile 1990-91”, NCES Statistical Study, January.

The News, 2004, 'Revamping of educational system key to development', March 23. available at http://www.jang.com.pk/thenews/mar2004-daily/23-03-2004/metro/k11.htm

Rahman, Tariq, 2005, Denizens of Alien Worlds: A Study of Education, Inequality and Polarization in Pakistan, Oxford University Press, Oxford.

Tooley, James, 2001. The Global Education Industry, $2^{\text {nd }}$ edition, Institute for Economic Affairs, London.

The United Nations, 2005, The Millennium Development Goals Report. New York

The World Bank, 2006. Pakistan Gender Assessment Report. The World Bank, Washington D.C. 
Tables and Figures

TABLE 1

COMPARING VILLAGES WITH AND WITHOUT PRIVATE SCHOOLS

\begin{tabular}{|c|c|c|c|c|c|c|c|c|c|c|}
\hline & \multicolumn{2}{|c|}{$\begin{array}{c}(1) \\
\text { All } 4 \text { Provinces }\end{array}$} & \multicolumn{2}{|c|}{$\begin{array}{c}\text { (2) } \\
\text { Punjab }\end{array}$} & \multicolumn{2}{|c|}{$\begin{array}{c}\text { (3) } \\
\text { Sindh }\end{array}$} & \multicolumn{2}{|c|}{$\begin{array}{c}\text { (4) } \\
\text { NWFP }\end{array}$} & \multicolumn{2}{|c|}{$\begin{array}{c}\text { (5) } \\
\text { Balochistan }\end{array}$} \\
\hline & $\begin{array}{l}\text { Villages } \\
\text { with a } \\
\text { private } \\
\text { school }\end{array}$ & $\begin{array}{l}\text { Villages } \\
\text { without } \\
\text { private } \\
\text { schools }\end{array}$ & $\begin{array}{l}\text { Villages } \\
\text { with a } \\
\text { private } \\
\text { school }\end{array}$ & $\begin{array}{l}\text { Villages } \\
\text { without } \\
\text { private } \\
\text { schools }\end{array}$ & $\begin{array}{l}\text { Villages } \\
\text { with a } \\
\text { private } \\
\text { school }\end{array}$ & $\begin{array}{l}\text { Villages } \\
\text { without } \\
\text { private } \\
\text { schools }\end{array}$ & $\begin{array}{l}\text { Villages } \\
\text { with a } \\
\text { private } \\
\text { school }\end{array}$ & $\begin{array}{l}\text { Villages } \\
\text { without } \\
\text { private } \\
\text { schools }\end{array}$ & $\begin{array}{l}\text { Villages } \\
\text { with a } \\
\text { private } \\
\text { school }\end{array}$ & $\begin{array}{l}\text { Villages } \\
\text { without } \\
\text { private } \\
\text { schools }\end{array}$ \\
\hline $\begin{array}{l}\text { Fraction } \\
\text { Enrolled }\end{array}$ & $\begin{array}{l}0.58 * \\
(0.02)\end{array}$ & $\begin{array}{l}0.41^{*} \\
(0.01)\end{array}$ & $\begin{array}{l}0.61 * \\
(0.02)\end{array}$ & $\begin{array}{l}0.46^{*} \\
(0.02)\end{array}$ & $\begin{array}{l}0.41^{*} \\
(0.05)\end{array}$ & $\begin{array}{l}0.31 * \\
(0.02)\end{array}$ & $\begin{array}{l}0.55^{*} \\
(0.03)\end{array}$ & $\begin{array}{l}0.42 * \\
(0.03)\end{array}$ & $\begin{array}{l}0.56^{*} \\
(0.02)\end{array}$ & $\begin{array}{l}0.41^{*} \\
(0.03)\end{array}$ \\
\hline $\begin{array}{l}\text { Fraction } \\
\text { Females } \\
\text { Enrolled }\end{array}$ & $\begin{array}{l}0.50^{*} \\
(0.02)\end{array}$ & $\begin{array}{l}0.29 * \\
(0.01)\end{array}$ & $\begin{array}{l}0.56^{*} \\
(0.03)\end{array}$ & $\begin{array}{l}0.35^{*} \\
(0.02)\end{array}$ & $\begin{array}{c}0.28 \\
(0.05)\end{array}$ & $\begin{array}{c}0.20 \\
(0.02)\end{array}$ & $\begin{array}{l}0.42 * \\
(0.04)\end{array}$ & $\begin{array}{l}0.24 * \\
(0.03)\end{array}$ & $\begin{array}{l}0.50^{*} \\
(0.05)\end{array}$ & $\begin{array}{l}0.26^{*} \\
(0.05)\end{array}$ \\
\hline $\begin{array}{l}\text { Fraction Males } \\
\text { Enrolled }\end{array}$ & $\begin{array}{l}0.66 * \\
(0.02)\end{array}$ & $\begin{array}{l}0.52 * \\
(0.01)\end{array}$ & $\begin{array}{l}0.67 * \\
(0.02)\end{array}$ & $\begin{array}{l}0.55^{*} \\
(0.02)\end{array}$ & $\begin{array}{c}0.55 \\
(0.08)\end{array}$ & $\begin{array}{c}0.42 \\
(0.03)\end{array}$ & $\begin{array}{c}0.68 \\
(0.03)\end{array}$ & $\begin{array}{c}0.59 \\
(0.04)\end{array}$ & $\begin{array}{l}0.65^{*} \\
(0.02)\end{array}$ & $\begin{array}{l}0.54^{*} \\
(0.03)\end{array}$ \\
\hline $\begin{array}{l}\text { Private Share } \\
\text { as a Fraction of } \\
\text { enrollment }\end{array}$ & $\begin{array}{l}0.20^{*} \\
(0.01)\end{array}$ & $\begin{array}{l}0.07 * \\
(0.01)\end{array}$ & $\begin{array}{l}0.23 * \\
(0.02)\end{array}$ & $\begin{array}{l}0.11^{*} \\
(0.02)\end{array}$ & $\begin{array}{c}0.05 \\
(0.03)\end{array}$ & $\begin{array}{c}0.02 \\
(0.01)\end{array}$ & $\begin{array}{l}0.16^{*} \\
(0.02)\end{array}$ & $\begin{array}{l}0.05^{*} \\
(0.01)\end{array}$ & $\begin{array}{c}0.06 \\
(0.03)\end{array}$ & $\begin{array}{c}0.01 \\
(0.01)\end{array}$ \\
\hline $\begin{array}{l}\text { Public share as } \\
\text { a Fraction of } \\
\text { enrollment }\end{array}$ & $\begin{array}{l}0.91 * \\
(0.01)\end{array}$ & $\begin{array}{l}0.78 * \\
(0.01)\end{array}$ & $\begin{array}{l}0.75^{*} \\
(0.02)\end{array}$ & $\begin{array}{l}0.87 * \\
(0.02)\end{array}$ & $\begin{array}{l}0.91 * \\
(0.03)\end{array}$ & $\begin{array}{l}0.97 * \\
(0.01)\end{array}$ & $\begin{array}{l}0.83^{*} \\
(0.02)\end{array}$ & $\begin{array}{l}0.92 * \\
(0.01)\end{array}$ & $\begin{array}{c}0.91 \\
(0.03)\end{array}$ & $\begin{array}{c}0.98 \\
(0.01)\end{array}$ \\
\hline $\begin{array}{l}\text { Private Share } \\
\text { as a Fraction of } \\
\text { enrollment } \\
\text { (POOR) }\end{array}$ & $\begin{array}{l}0.13^{*} \\
(0.02)\end{array}$ & $\begin{array}{l}0.03^{*} \\
(0.01)\end{array}$ & $\begin{array}{l}0.15^{*} \\
(0.02)\end{array}$ & $\begin{array}{c}0.5^{*} \\
(0.01)\end{array}$ & $\begin{array}{c}0.02 \\
(0.02)\end{array}$ & $\begin{array}{c}0.00 \\
(0.00)\end{array}$ & $\begin{array}{c}0.07 \\
(0.04)\end{array}$ & $\begin{array}{c}0.02 \\
(0.01)\end{array}$ & 0 obs & 0 obs \\
\hline $\begin{array}{l}\text { Private Share } \\
\text { as a Fraction of } \\
\text { enrollment } \\
\text { (MIDDLE) }\end{array}$ & $\begin{array}{l}0.16^{*} \\
(0.02)\end{array}$ & $\begin{array}{l}0.07^{*} \\
(0.02)\end{array}$ & $\begin{array}{c}0.20 \\
(0.02)\end{array}$ & $\begin{array}{c}0.12 \\
(0.03)\end{array}$ & $\begin{array}{c}0.05 \\
(0.02)\end{array}$ & $\begin{array}{c}0.02 \\
(0.01)\end{array}$ & $\begin{array}{c}0.08 \\
(0.02)\end{array}$ & $\begin{array}{c}0.04 \\
(0.01)\end{array}$ & $\begin{array}{l}0.24 * \\
(0.05)\end{array}$ & $\begin{array}{l}0.00 * \\
(0.00)\end{array}$ \\
\hline $\begin{array}{l}\text { Private Share } \\
\text { as a Fraction of } \\
\text { enrollment } \\
\text { (RICH) }\end{array}$ & $\begin{array}{l}0.26^{*} \\
(0.02)\end{array}$ & $\begin{array}{l}0.11 * \\
(0.02)\end{array}$ & $\begin{array}{c}0.29 \\
(0.02)\end{array}$ & $\begin{array}{c}0.18 \\
(0.03)\end{array}$ & $\begin{array}{c}0.06 \\
(0.04)\end{array}$ & $\begin{array}{c}0.04 \\
(0.01)\end{array}$ & $\begin{array}{l}0.24^{*} \\
(0.03)\end{array}$ & $\begin{array}{l}0.09 * \\
(0.03)\end{array}$ & $\begin{array}{c}0.05 \\
(0.01)\end{array}$ & $\begin{array}{c}0.03 \\
(0.01)\end{array}$ \\
\hline $\begin{array}{l}\text { Source: PIHS } 1 \\
\text { Standard error o } \\
\text { use the given po } \\
\text { households in te }\end{array}$ & $\begin{array}{l}\text { PEIP } \\
\text { he mear } \\
\text { lation a } \\
\text { s of cor }\end{array}$ & $\begin{array}{l}0 . \\
\text { parent } \\
5-15.1 \\
\text { mption }\end{array}$ & $\begin{array}{l}\text { s. }{ }^{*} \text { sig } \\
\text { oor, } \mathrm{n} \\
\text { he nat }\end{array}$ & $\begin{array}{l}\text { s the } \\
\text { le and } \\
\text { rural }\end{array}$ & $\begin{array}{l}\text { ence is } \\
\text { re resp } \\
\text { ation. }\end{array}$ & $\begin{array}{l}\text { ifican } \\
\text { vely th }\end{array}$ & $\begin{array}{l}\text { ne } 5 \% \\
\text { vest, } t\end{array}$ & $\begin{array}{l}\text { 1. Not } \\
\text { iddle }\end{array}$ & $\begin{array}{l}\text { Enroll } \\
\text { he top- }\end{array}$ & $\begin{array}{l}\text { figures } \\
\text { ird of all }\end{array}$ \\
\hline
\end{tabular}




\begin{tabular}{|c|c|c|c|}
\hline $\begin{array}{r}\text { DETE } \\
\text { Dependent } V\end{array}$ & $\begin{array}{l}\text { TA } \\
\text { JANTS OF S } \\
\text { le: Chilc }\end{array}$ & $\begin{array}{l}\text { ENROLLMEI } \\
\text { Lment Dummy }\end{array}$ & able \\
\hline & (1) & (2) & (3) \\
\hline Female & $\begin{array}{c}-0.163 \\
(0.012)^{* * *}\end{array}$ & $\begin{array}{c}-0.166 \\
(0.003)^{* * *}\end{array}$ & $\begin{array}{c}-0.182 \\
(0.003)^{* * *}\end{array}$ \\
\hline Private School in Settlement & $\begin{array}{c}0.164 \\
(0.020)^{* * *}\end{array}$ & $\begin{array}{c}0.076 \\
(0.004)^{* * *}\end{array}$ & \\
\hline $\begin{array}{l}\text { Female and Private School in } \\
\text { Settlement }\end{array}$ & $\begin{array}{c}0.081 \\
(0.014)^{* * *}\end{array}$ & $\begin{array}{c}0.081 \\
(0.004)^{* * *}\end{array}$ & $\begin{array}{c}0.096 \\
(0.004)^{* * *}\end{array}$ \\
\hline $\begin{array}{l}\text { Monthly Expenditure: Rs } \\
\text { 2500-5000 }\end{array}$ & $\begin{array}{c}0.078 \\
(0.016)^{* * *}\end{array}$ & $\begin{array}{c}0.074 \\
(0.003)^{* * *}\end{array}$ & \\
\hline $\begin{array}{l}\text { Monthly Expenditure: >Rs } \\
5000\end{array}$ & $\begin{array}{c}0.110 \\
(0.021)^{* * *}\end{array}$ & $\begin{array}{c}0.120 \\
(0.003)^{* * *}\end{array}$ & \\
\hline Age & $\begin{array}{c}0.147 \\
(0.007)^{* * *}\end{array}$ & $\begin{array}{c}0.143 \\
(0.002)^{* * *}\end{array}$ & $\begin{array}{c}0.146 \\
(0.002)^{* * *}\end{array}$ \\
\hline Age Squared & $\begin{array}{c}-0.008 \\
(0.000)^{* * *}\end{array}$ & $\begin{array}{c}-0.008 \\
(0.000)^{* * *}\end{array}$ & $\begin{array}{c}-0.008 \\
(0.000)^{* * *}\end{array}$ \\
\hline Illiterate Head & $\begin{array}{c}-0.242 \\
(0.012)^{* * *}\end{array}$ & $\begin{array}{c}-0.202 \\
(0.002)^{* * *}\end{array}$ & \\
\hline Constant & $\begin{array}{c}0.073 \\
(0.044)^{*}\end{array}$ & $\begin{array}{c}0.139 \\
(0.012)^{* * *}\end{array}$ & $\begin{array}{c}0.131 \\
(0.011)^{* * *}\end{array}$ \\
\hline Fixed Effects & none & Village Level & Household Level \\
\hline Observations & 147704 & 147704 & 149938 \\
\hline R-squared & 0.18 & 0.12 & 0.09 \\
\hline \multicolumn{4}{|c|}{$\begin{array}{l}\text { Source: LEAPS } 2003 \text { Household Survey } \\
* \text { significant at } 10 \% ; * * \text { significant at } 5 \% \text {; } * * * \text { significant at } 1 \% \\
\text { Notes: OLS regression. Robust standard errors in parenthesis. Errors are clustered at the village level } \\
\text { Observations are all children ages } 5 \text { to } 15 \text {. Omitted categories for dummy variables are: household has } \\
\text { literate head; monthly expenditure is below Rs. } 2500 \text {; no private school in settlement; and child is male }\end{array}$} \\
\hline
\end{tabular}




\begin{tabular}{|c|c|c|c|c|c|}
\hline \multicolumn{6}{|c|}{$\begin{array}{c}\text { TABLE } 3 \\
\text { WNED (FOR-PROFIT) PRIN }\end{array}$} \\
\hline Province & Region & Median & Mean & $\begin{array}{l}\text { Inter-quartile } \\
\text { range }\end{array}$ & Number of Schools \\
\hline \multirow[t]{2}{*}{ NWFP } & Urban & 1232 & $\begin{array}{c}1439 \\
(1360)\end{array}$ & 844 & 547 \\
\hline & Rural & 1152 & $\begin{array}{l}1249 \\
(1276)\end{array}$ & 600 & 1167 \\
\hline \multirow[t]{2}{*}{ Punjab } & Urban & 828 & $\begin{array}{l}1176 \\
(3112)\end{array}$ & 622 & 4290 \\
\hline & Rural & 600 & $\begin{array}{c}723 \\
(943)\end{array}$ & 403 & 3897 \\
\hline \multirow[t]{2}{*}{ Sindh } & Urban & 1208 & $\begin{array}{l}1947 \\
(3079)\end{array}$ & 1126 & 1325 \\
\hline & Rural & 1080 & $\begin{array}{c}979 \\
(541)\end{array}$ & 720 & 77 \\
\hline \multirow[t]{2}{*}{ Balochistan } & Urban & 1757 & $\begin{array}{l}1833 \\
(948)\end{array}$ & 1200 & 61 \\
\hline & Rural & 1265 & $\begin{array}{l}1293 \\
(734)\end{array}$ & 669 & 42 \\
\hline \multirow[t]{2}{*}{ All Pakistan } & Urban & 960 & $\begin{array}{l}1426 \\
(3492)\end{array}$ & 866 & 6397 \\
\hline & Rural & 751 & $\begin{array}{c}892 \\
(1000)\end{array}$ & 638 & 6001 \\
\hline
\end{tabular}




\begin{tabular}{|c|c|c|c|c|}
\hline \multicolumn{5}{|c|}{$\begin{array}{c}\text { TABLE } 4 \\
\text { TEACHER CHARACTERISTICS } \\
\text { PUBLIC AND PRIVATE SCHOOLS }\end{array}$} \\
\hline \multirow[b]{2}{*}{ (log) Salary } & Units & $\begin{array}{l}\text { Public } \\
\text { Mean }\end{array}$ & $\begin{array}{c}\text { Private } \\
\text { Mean }\end{array}$ & $\begin{array}{c}\text { Difference of Means } \\
{[\mathrm{z} \text { or } t \text { - statistic }]}\end{array}$ \\
\hline & (log Rs.) & $\begin{array}{c}8.63 \\
(0.01)\end{array}$ & $\begin{array}{c}6.99 \\
(0.01)\end{array}$ & $\begin{array}{c}1.65 \\
{[106.92]}\end{array}$ \\
\hline \multirow[t]{2}{*}{ Gender } & (Fraction Male) & 0.5708 & 0.2377 & 0.33 \\
\hline & & $(0.01)$ & $(0.01)$ & [23.31] \\
\hline \multirow[t]{2}{*}{ Age } & (Years) & 38.6 & 25.2 & 13.4 \\
\hline & & $(0.16)$ & $(0.17)$ & {$[57.70]$} \\
\hline \multirow{2}{*}{ Marital Status } & (Fraction Single) & 0.15 & 0.77 & 0.63 \\
\hline & & $(0.02)$ & $(0.02)$ & {$[-17.71]$} \\
\hline \multirow[t]{2}{*}{ Origin } & (Fraction Local) & 0.25 & 0.52 & 0.27 \\
\hline & & $(0.01)$ & (0.01) & {$[-19.12]$} \\
\hline \multirow[t]{7}{*}{ Education } & \% Matric and below & $\begin{array}{c}0.36 \\
(0.01)\end{array}$ & $\begin{array}{c}0.41 \\
(0.01)\end{array}$ & $\begin{array}{c}0.06 \\
{[-4.21]}\end{array}$ \\
\hline & $\%$ FA/FSc & 0.19 & 0.36 & 0.17 \\
\hline & & $(0.01)$ & $(0.01)$ & {$[-13.06]$} \\
\hline & $\% \mathrm{BA} / \mathrm{BSc}$ & 0.26 & 0.19 & 0.07 \\
\hline & & $(0.01)$ & $(0.01)$ & [6.08] \\
\hline & $\% \mathrm{MA} / \mathrm{MSc}$ & 0.19 & 0.04 & 0.15 \\
\hline & & $(0.01)$ & $(0.04)$ & {$[16.20]$} \\
\hline \multirow[t]{8}{*}{ Training } & \% No Training & 0.06 & 0.71 & 0.65 \\
\hline & & $(0.00)$ & $(0.01)$ & {$[-46.37]$} \\
\hline & \% PTC/JV/SV & 0.44 & 0.15 & 0.29 \\
\hline & & $(0.01)$ & $(0.01)$ & [21.45] \\
\hline & \% CT & 0.22 & 0.08 & 0.15 \\
\hline & & $(0.01)$ & $(0.01)$ & [13.50] \\
\hline & \% BEd and above & 0.28 & 0.06 & 0.21 \\
\hline & & $(0.01)$ & $(0.01)$ & [18.71] \\
\hline \multirow[t]{6}{*}{ Teaching Experience } & $\%<1$ year & 0.06 & 0.21 & 0.15 \\
\hline & & $(0.00)$ & $(0.01)$ & {$[-15.19]$} \\
\hline & $\% 1-3$ years & 0.05 & 0.39 & 0.34 \\
\hline & & $(0.00)$ & $(0.01)$ & {$[-29.00]$} \\
\hline & $\%>3$ years & 0.88 & 0.40 & 0.49 \\
\hline & & $(0.01)$ & $(0.01)$ & [35.61] \\
\hline
\end{tabular}




\section{TABLE 5}

HOW ARE PRIVATE SCHOOLS DIFFERENT? : DETERMINANTS OF TEACHER COMPENSATION Dependent Variable: $\log$ Teacher Salary in Rs. $(\$ 1=$ Rs.60.20 $)$

(1)

\section{Public Schools}

Female

Local

Female*Private

Local*Private

Private

Education: F.A./F.Sc..

Education: B.A./B.Sc.

Education: M.A./M.Sc. or above

Training: PTC/JV/SV

Training: CT

Training: B.Ed. or above

Experience: $1-3$ years

Experience: $>3$ years

\section{Age}

\section{Age Squared}

Constant

Fixed Effects

Observations

R-squared

Source: LEAPS 2003 Teacher Roster

* significant at $10 \%$; ** significant at $5 \%$; *** significant at $1 \%$

Robust standard errors in parentheses. Errors are clustered at the village level.

Omitted categories for dummy variables are Male, Public School, Not teaching in home village, Education: Matric and below, No Training, and Experience $<1$ year.
(3)

\section{Private Schools}

-0.333
$(0.052) * * *$

$-0.231$

$(0.037)^{* * *}$
All Schools

0.023

(0.019)

$-0.066$

$(0.024)^{* * *}$

$-0.291$

$(0.053)^{* * *}$

$-0.143$

$(0.049)^{* * *}$

$-0.721$

$(0.045)^{* * *}$

0.159

$(0.022)^{* * *}$

0.333

$(0.030)^{* * *}$

0.475

$(0.039)^{* * *}$

0.256

$(0.044)^{* * *}$

0.186

$(0.037)^{* * *}$

0.278

$(0.042)^{* * *}$

0.135

$(0.031)^{* * *}$

0.217

$(0.034)^{* * *}$

0.038

$(0.009)^{* * *}$

0
$(0.000)^{* *}$

6.931

$(0.172)^{* * *}$

none

4552

0.83
(4)

All Schools

0.025

(0.02)

$-0.065$

$(0.025)^{* *}$

$-0.275$

$(0.047)^{* * *}$

$-0.082$

(0.044)*

$-0.797$

$(0.045)^{* * *}$

0.145

$(0.020)^{* * *}$

0.312

$(0.027)^{* * *}$

0.475

$(0.038)^{* * *}$

0.252

$(0.044)^{* * *}$

0.193

$(0.036)^{* * *}$

0.274

$(0.040)^{* * *}$

0.117

$(0.027)^{* * *}$

$$
0.21
$$

$(0.032)^{* * *}$

0.04

$(0.008)^{* * *}$

0

$(0.000)^{* * *}$

6.926

$(0.155)^{* * *}$

Village Level

4552

0.85 


\begin{tabular}{|c|c|c|c|c|c|c|c|c|c|c|}
\hline \multicolumn{11}{|c|}{$\begin{array}{c}\text { TABLE } 6 \\
\text { VILLAGE ATTRIBUTES } \\
\text { VILLAGES WITH AND WITHOUT PRIVATE SCHOOLS }\end{array}$} \\
\hline & \multicolumn{2}{|c|}{ All 4 Provinces } & \multicolumn{2}{|c|}{ Punjab } & \multicolumn{2}{|c|}{ Sindh } & \multicolumn{2}{|c|}{ NWFP } & \multicolumn{2}{|c|}{ Balochistan } \\
\hline & $\begin{array}{l}\text { Villages } \\
\text { with a } \\
\text { private } \\
\text { school }\end{array}$ & $\begin{array}{l}\text { Villages } \\
\text { without } \\
\text { private } \\
\text { schools }\end{array}$ & $\begin{array}{l}\text { Villages } \\
\text { with a } \\
\text { private } \\
\text { school }\end{array}$ & $\begin{array}{l}\text { Villages } \\
\text { without } \\
\text { private } \\
\text { schools }\end{array}$ & $\begin{array}{l}\text { Villages } \\
\text { with a } \\
\text { private } \\
\text { school }\end{array}$ & $\begin{array}{l}\text { Villages } \\
\text { without } \\
\text { private } \\
\text { schools }\end{array}$ & $\begin{array}{l}\text { Villages } \\
\text { with a } \\
\text { private } \\
\text { school }\end{array}$ & $\begin{array}{c}\text { Villages } \\
\text { without } \\
\text { private } \\
\text { schools }\end{array}$ & $\begin{array}{l}\text { Villages } \\
\text { with a } \\
\text { private } \\
\text { school }\end{array}$ & $\begin{array}{l}\text { Villages } \\
\text { without } \\
\text { private } \\
\text { schools }\end{array}$ \\
\hline $\begin{array}{l}\text { Number of } \\
\text { Settlements }\end{array}$ & 6942 & 36556 & 5253 & 19285 & 388 & 5391 & 1238 & 5937 & 63 & 5943 \\
\hline $\begin{array}{l}\text { Mean } \\
\text { Population }\end{array}$ & $\begin{array}{l}4465^{*} \\
(54.0)\end{array}$ & $\begin{array}{c}1502 * \\
(9.6)\end{array}$ & $\begin{array}{l}4051^{*} \\
(54.2)\end{array}$ & $\begin{array}{l}1518^{*} \\
(11.5)\end{array}$ & $\begin{array}{c}4921 * \\
(301.8)\end{array}$ & $\begin{array}{l}2539 * \\
(35.6)\end{array}$ & $\begin{array}{c}6102 * \\
(158.8)\end{array}$ & $\begin{array}{l}1212^{*} \\
(21.1)\end{array}$ & $\begin{array}{c}4038 * \\
(692.6)\end{array}$ & $\begin{array}{c}797 * \\
(19.6)\end{array}$ \\
\hline $\begin{array}{l}\text { Fraction } \\
\text { Literate Adults }\end{array}$ & $\begin{array}{l}0.428^{*} \\
(0.002)\end{array}$ & $\begin{array}{l}0.281^{*} \\
(0.001)\end{array}$ & $\begin{array}{l}0.455^{*} \\
(0.002)\end{array}$ & $\begin{array}{l}0.350 * \\
(0.001)\end{array}$ & $\begin{array}{l}0.255^{*} \\
(0.007)\end{array}$ & $\begin{array}{l}0.213^{*} \\
(0.002)\end{array}$ & $\begin{array}{l}0.375^{*} \\
(0.004)\end{array}$ & $\begin{array}{l}0.242 * \\
(0.002)\end{array}$ & $\begin{array}{l}0.285^{*} \\
(0.019)\end{array}$ & $\begin{array}{l}0.143 * \\
(0.002)\end{array}$ \\
\hline $\begin{array}{l}\text { Fraction } \\
\text { Permanent } \\
\text { Houses }\end{array}$ & $\begin{array}{l}0.596 * \\
(0.004)\end{array}$ & $\begin{array}{l}0.361^{*} \\
(0.002)\end{array}$ & $\begin{array}{l}0.646 * \\
(0.004)\end{array}$ & $\begin{array}{l}0.452 * \\
(0.002)\end{array}$ & $\begin{array}{l}0.183 * \\
(0.011)\end{array}$ & $\begin{array}{l}0.123^{*} \\
(0.002)\end{array}$ & $\begin{array}{l}0.536 * \\
(0.009)\end{array}$ & $\begin{array}{l}0.565^{*} \\
(0.004)\end{array}$ & $\begin{array}{c}0.079 \\
(0.004)\end{array}$ & $\begin{array}{c}0.077 \\
(0.003)\end{array}$ \\
\hline $\begin{array}{l}\text { Fraction Houses } \\
\text { with Water }\end{array}$ & $\begin{array}{l}0.152 * \\
(0.003)\end{array}$ & $\begin{array}{l}0.088^{*} \\
(0.001)\end{array}$ & $\begin{array}{l}0.125 * \\
(0.003)\end{array}$ & $\begin{array}{l}0.076 * \\
(0.001)\end{array}$ & $\begin{array}{l}0.130 * \\
(0.010)\end{array}$ & $\begin{array}{l}0.100^{*} \\
(0.002)\end{array}$ & $\begin{array}{l}0.268 * \\
(0.008)\end{array}$ & $\begin{array}{l}0.151^{*} \\
(0.004)\end{array}$ & $\begin{array}{l}0.320^{*} \\
(0.004)\end{array}$ & $\begin{array}{l}0.050^{*} \\
(0.002)\end{array}$ \\
\hline $\begin{array}{l}\text { Fraction } \\
\text { Houses with } \\
\text { Electricity }\end{array}$ & $\begin{array}{l}0.736 * \\
(0.003)\end{array}$ & $\begin{array}{l}0.435 * \\
(0.002)\end{array}$ & $\begin{array}{l}0.762 * \\
(0.003)\end{array}$ & $\begin{array}{l}0.513^{*} \\
(0.003)\end{array}$ & $\begin{array}{c}0.407 \\
(0.017)\end{array}$ & $\begin{array}{c}0.425 \\
(0.005)\end{array}$ & $\begin{array}{l}0.741^{*} \\
(0.008)\end{array}$ & $\begin{array}{l}0.414^{*} \\
(0.004)\end{array}$ & $\begin{array}{l}0.539 * \\
(0.004)\end{array}$ & $\begin{array}{l}0.213^{*} \\
(0.005)\end{array}$ \\
\hline $\begin{array}{l}\text { Average } \\
\text { Household Size }\end{array}$ & $\begin{array}{l}7.1^{*} \\
(0.01)\end{array}$ & $\begin{array}{l}6.67 * \\
(0.01)\end{array}$ & $\begin{array}{l}6.99 * \\
(0.01)\end{array}$ & $\begin{array}{l}6.78^{*} \\
(0.01)\end{array}$ & $\begin{array}{l}5.56^{*} \\
(0.04)\end{array}$ & $\begin{array}{l}5.45^{*} \\
(0.01)\end{array}$ & $\begin{array}{l}8.06^{*} \\
(0.04)\end{array}$ & $\begin{array}{l}7.76^{*} \\
(0.02)\end{array}$ & $\begin{array}{l}6.23 \\
(0.24)\end{array}$ & $\begin{array}{c}6.36 \\
(0.03)\end{array}$ \\
\hline Village Area & $\begin{array}{l}2755^{*} \\
(63.5)\end{array}$ & $\begin{array}{l}2209 * \\
(26.8)\end{array}$ & $\begin{array}{l}2109 * \\
(43.4)\end{array}$ & $\begin{array}{l}1523 * \\
(20.5)\end{array}$ & $\begin{array}{c}8337 * \\
(659.9)\end{array}$ & $\begin{array}{c}4302 * \\
(109.7)\end{array}$ & $\begin{array}{c}3807 * \\
(198.7)\end{array}$ & $\begin{array}{l}2371 * \\
(92.3)\end{array}$ & $\begin{array}{c}3914 \\
(800.8)\end{array}$ & $\begin{array}{c}2619 \\
(82.6)\end{array}$ \\
\hline
\end{tabular}




\section{TABLE 7}

\section{PUBLIC-PRIVATE COMPLEMENTARITY}

Villages with Private Schools (\%)

Does not have girls primary or secondary school

Received girls primary only in last 20 years

Received girls primary and

secondary in last 20 years
Number of educated Number of women per village educated women per 1000

population

Source: Population Census 1998, PEIP 2000, EMIS 2000 
Figure 1: The Growth of Private Schools

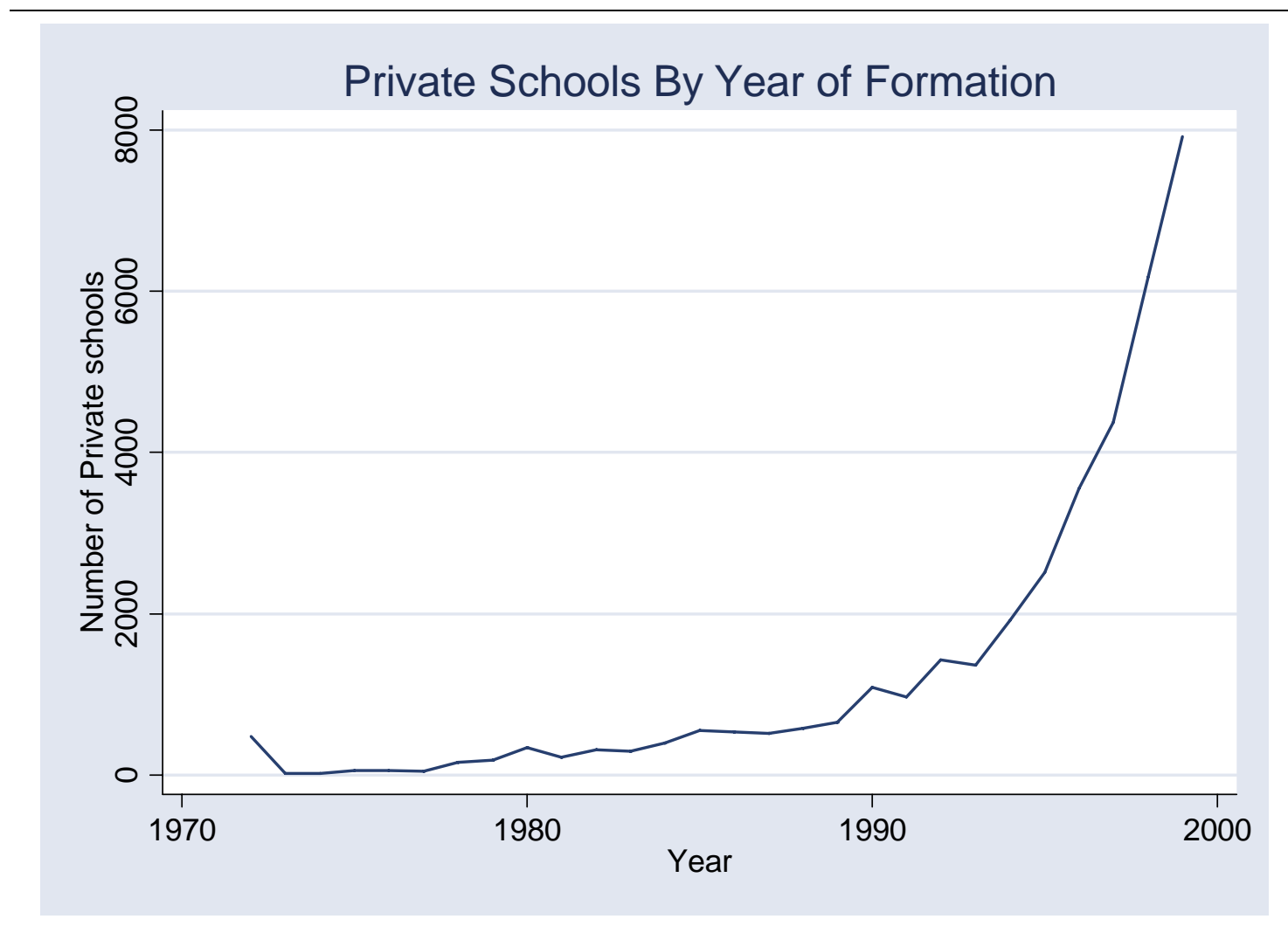

Notes: The figure shows the number of private schools in 2000 that were set up in each of the relevant years. For instance, of all the schools in the country in 2000, 8000 were set up in 2000, 7000 were set up in 199 and only 200 were setup in 1980. The data are from the census of private schools carried out by the Federal Bureau of Statistics in 2001. We omit the last year, since the survey was carried out at the beginning of the year. 


\section{Figure 2: Growth Rate of enrollment in public and private schools}

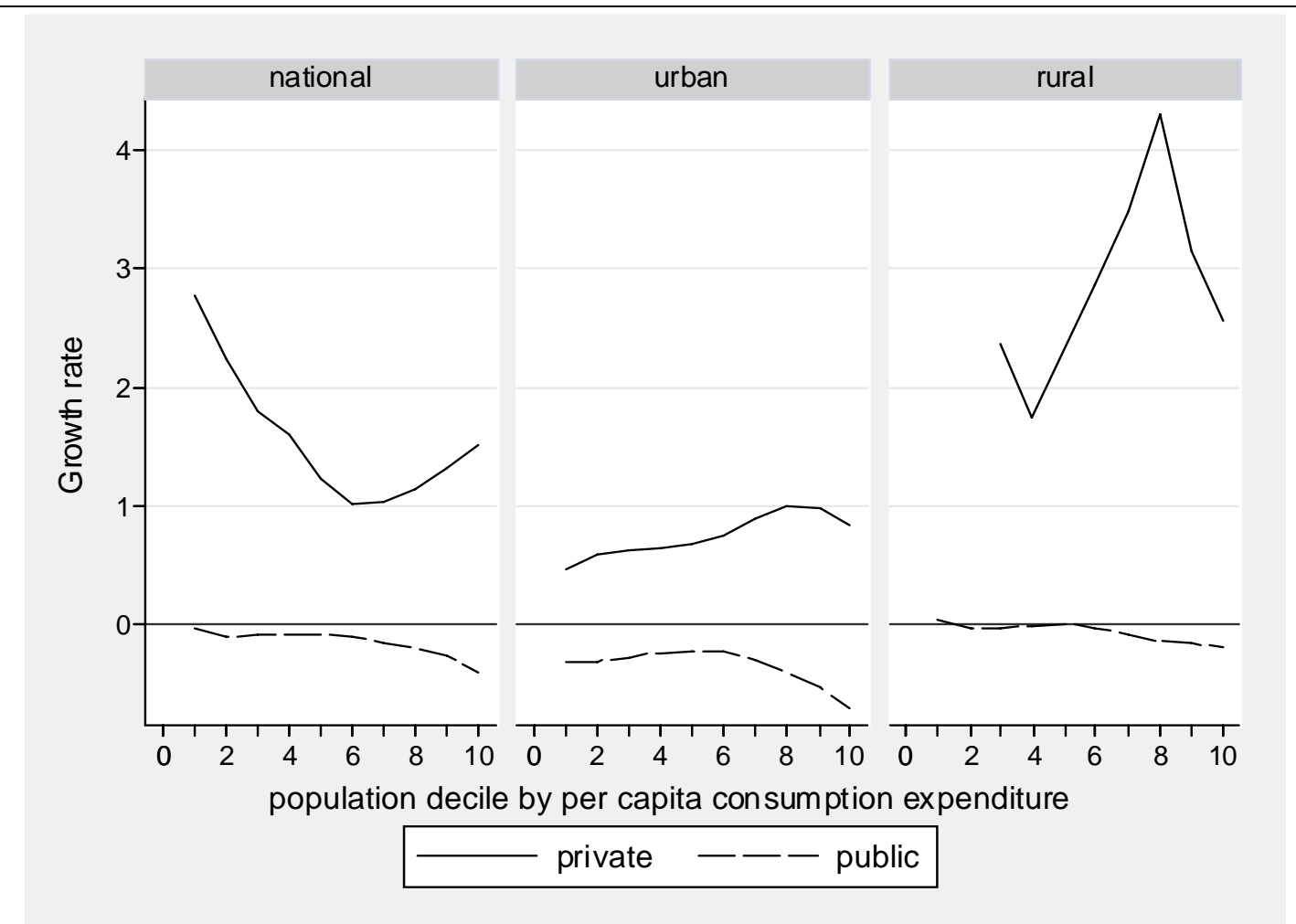

Notes: Based on PIHS data, 1991 and 2001. The horizontal axis shows income deciles ranked in order of increasing income at the national, rural and urban levels. The vertical axis shows the growth in net enrollment rate in the private and public sector. Thus, for instance, the national figure shows that highest growth was among the lowest income deciles, but that within rural and within urban areas higher income deciles saw greater growth in private schooling during the nineties. Across all regions and income deciles, there was a decline in public sector growth during the nineties. Note that growth rates could not be calculated for the bottom two deciles in rural areas, since the initial level was zero. 


\section{Figure 3: Enrollment and School-Presence}

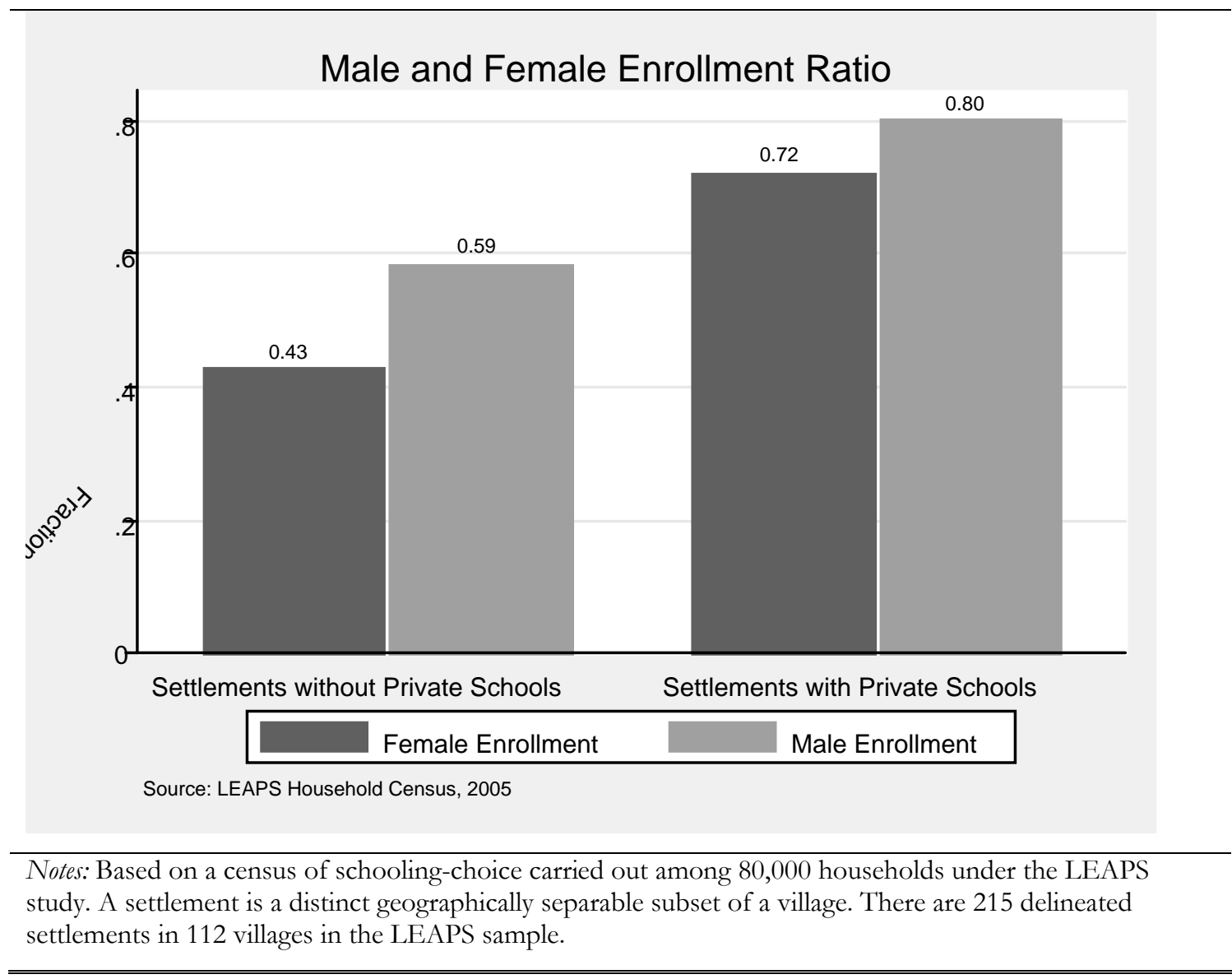


Figure 4: Teacher Salaries: The Public/Private Wage Gap

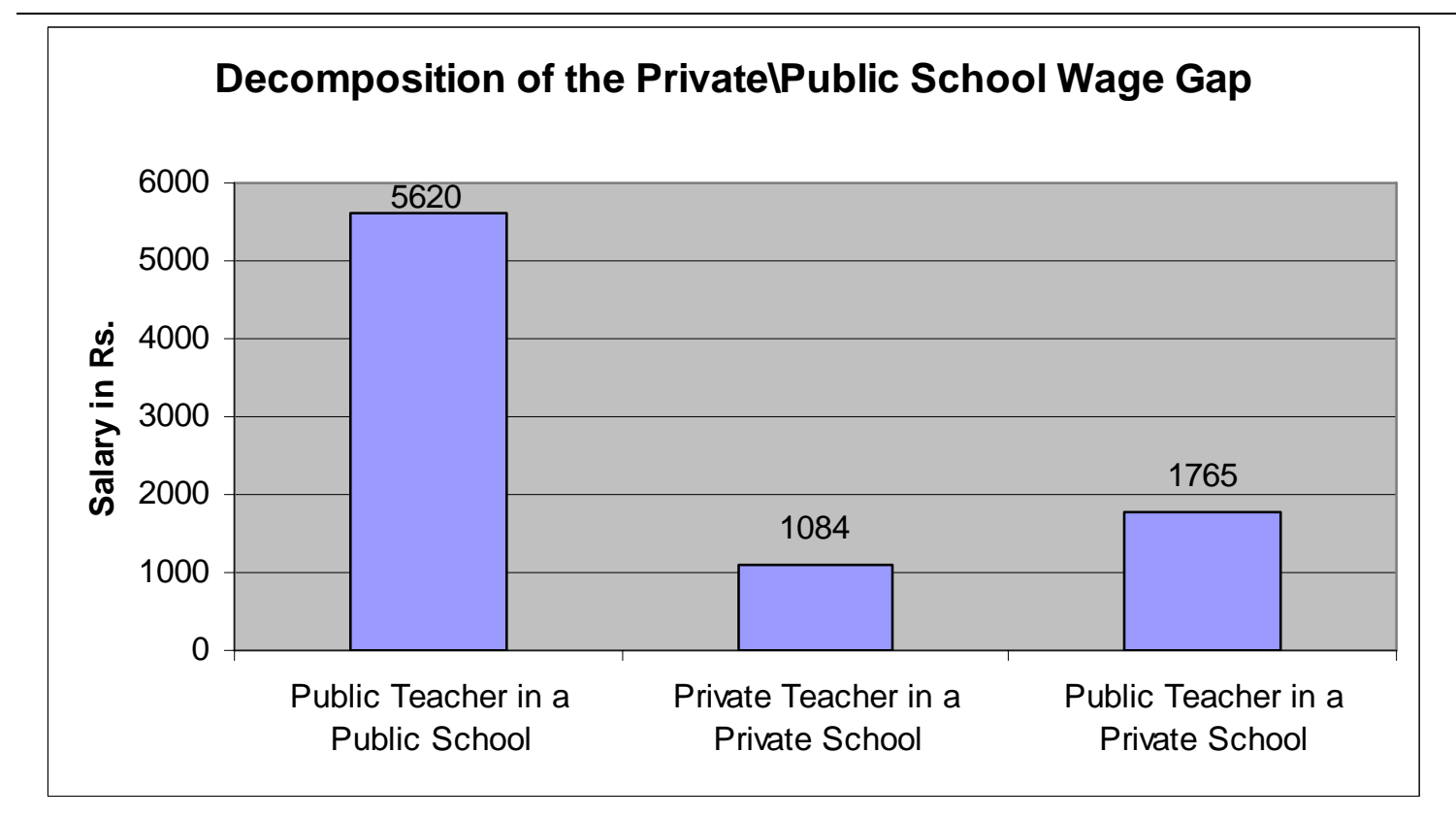

Notes: Based on a census of 4,830 teachers in 810 public and private schools carried out as part of the LEAPS surveys. The first bar shows the average wage of a public school teacher; the second shows the average wage of a private school teacher. The third bar presents the wage a teacher with the characteristics of a public school teacher would earn if he/she were to move to a private school. This predicted wage is based on a regression of private school wages on gender, whether the teacher is local, age, training, education, experience, and absenteeism. 
Figure 5: Decomposition of the Public/Private Wage Gap

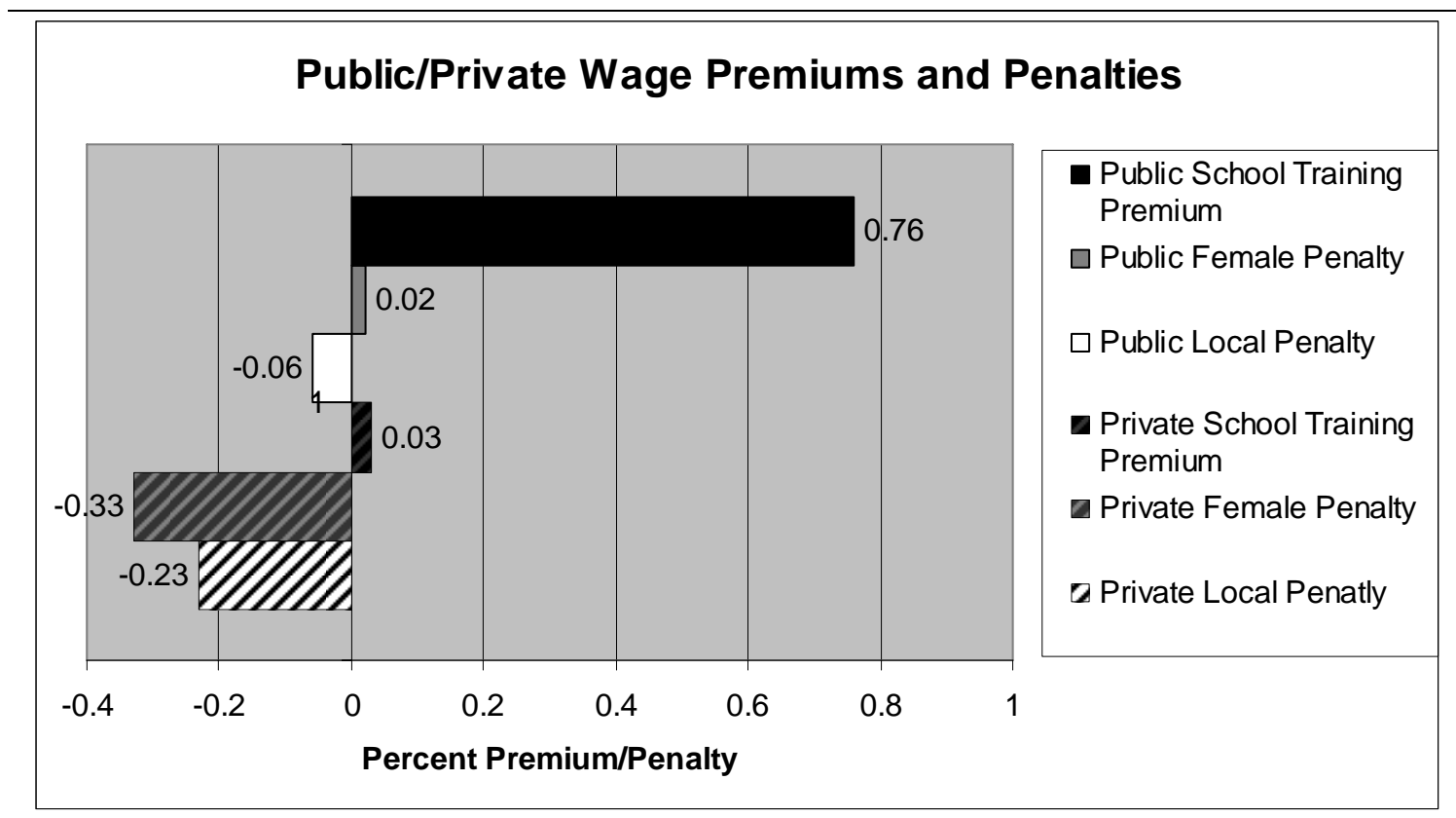

Notes: Based on a census of 4,830 teachers in 810 public and private schools carried out as part of the LEAPS surveys. The figure plots the coefficients presented in Table 5, which explains wages in the public and private sector as a function of training, gender, residence, education, absenteeism, age and experience. Positive numbers are premiums, negative are penalties. 
Figure 6: Teacher Absenteeism

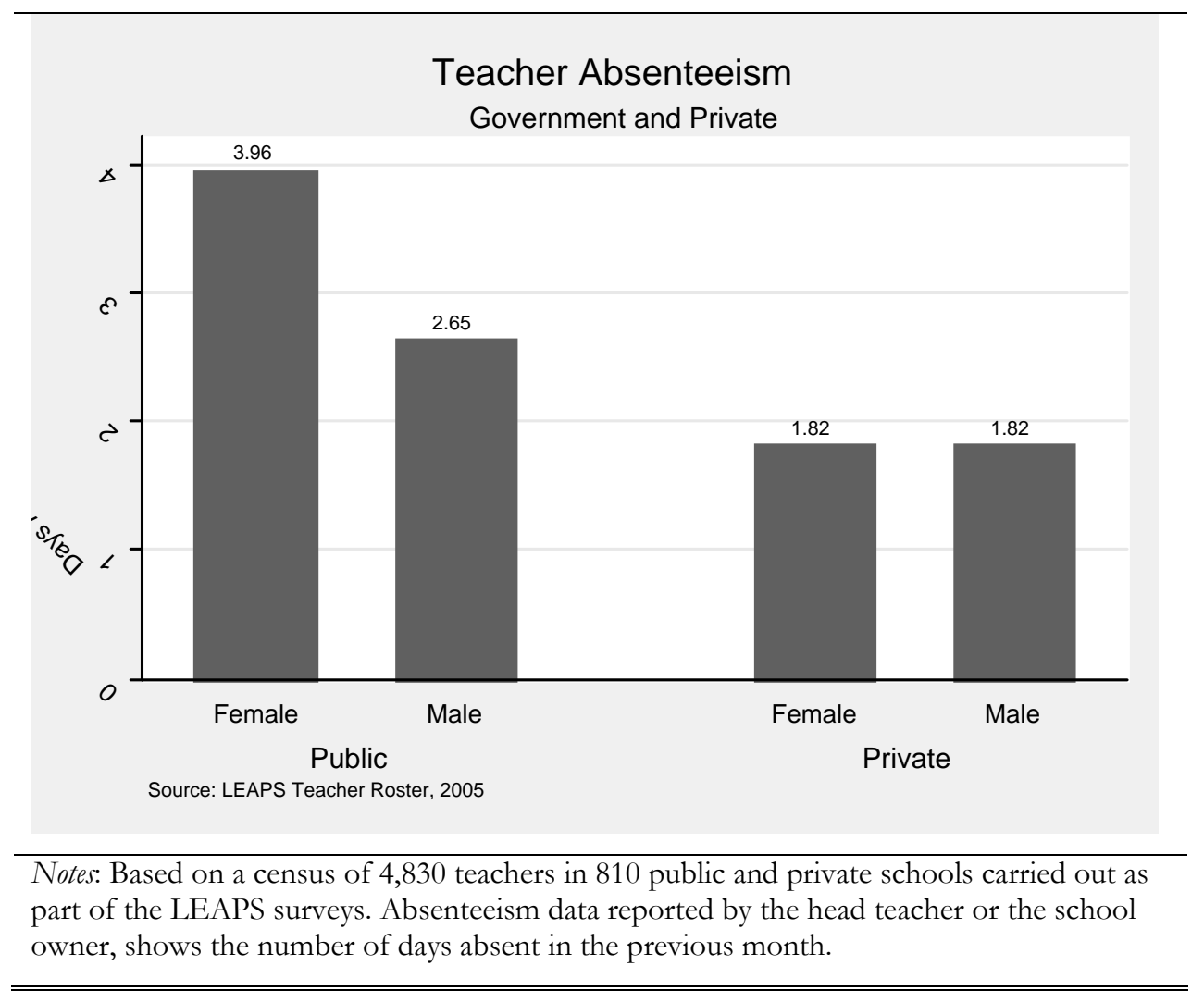

